\title{
Jejak Lahan Sistem Pertanian Terpadu Tanaman-Ternak di Kabupaten Bojonegoro, Jawa Timur
}

\section{Land Footprint of Integrated Crop-Livestock Farming System in Bojonegoro District, East Java}

\author{
Sofyan Zaman ${ }^{1}$, Edi Santosa ${ }^{1 *}$, Panca Dewi Manuhara Karti ${ }^{2}$, Herdhata Agusta ${ }^{1}$, dan Muladno ${ }^{3}$ \\ ${ }^{1}$ Departemen Agronomi dan Hortikultura, Fakultas Pertanian, Institut Pertanian Bogor \\ (IPB University), Jl. Meranti, Kampus IPB Darmaga, Bogor 16680, Indonesia \\ ${ }^{2}$ Departemen Ilmu Nutrisi dan Teknologi Pakan, Fakultas Peternakan, Institut Pertanian Bogor \\ (IPB University), Jl. Agatis, Kampus IPB Darmaga, Bogor 16680, Indonesia \\ ${ }^{3}$ Departemen Ilmu Produksi dan Teknologi Peternakan, Fakultas Peternakan, Institut Pertanian Bogor \\ (IPB University), Jl. Agatis, Kampus IPB Darmaga, Bogor 16680, Indonesia
}

Diterima 2 Mei 2020/Disetujui 23 Juli 2020

\begin{abstract}
Land footprint is one indicator of ecological capacity for developing sustainable agriculture systems. The study aimed to evaluate the ecological capacity of integrated farming agriculture-livestock through land footprint in order to develop integrated sustainable agriculture. The research was conducted in May-August 2019 at Sekaran Village, Bojonegoro District, East Java, Indonesia. Food availability index (FAI) and feed carrying capacity index (FCC) was calculated from reports and interview. The evaluation showed annual FAI was 3.4 and FCC was 7.2. Foodland footprint was 143.2 ha and cattleland footprint was $759.1 \mathrm{ha}$. Total land footprint for food-feed was $759.1 \mathrm{ha}$, below total available land for agronomic activities of 1,574 ha, indicating sufficient ecological capacity to support integrated farming systems. However, the FCC in April-May < 1 , indicating insecurity fodder availability to support the existing cattle population. Based on feed availability, the maximum amount for cow breeding stock was 713 and for fattening was 24 cows. The fattening population could be increased up to 1,590-2,515 by increasing fodder availability through silage production, planting king grass, and drought tolerant tree crops to sustain the integration.
\end{abstract}

Keywords: cow, ecological footprint, fattening, food availability index, sustainable farming

\section{ABSTRAK}

Jejak lahan merupakan salah satu indikator untuk mengukur daya dukung lingkungan suatu sistem pertanian berkelanjutan. Penelitian bertujuan mengevaluasi daya dukung lingkungan sistem pertanian terpadu dan ternak melalui pendekatan jejak lahan dalam rangka membangun usaha pertanian berkelanjutan. Penelitian dilakukan pada Mei-Agustus 2019 di Desa Sekaran, Bojonegoro, Jawa Timur. Data indeks ketersediaan pangan (IKP) dan indeks daya dukung pakan (IDD) diformulasikan dari laporan dan wawancara. Hasil menunjukkan IKP dan IDD tahunan dalam katagori cukup dengan nilai 3.4 dan 7.2. Jejak lahan pangan adalah 143.2 ha dan jejak lahan pakan adalah 759.1 ha yang mencakup jejak lahan pakan asal limbah pertanian tanaman pangan dan hijauan. Nilai jejak lahan total pangan-pakan yakni 759.1 ha lebih rendah daripada luas lahan tersedia untuk kegiatan agronomi yakni 1,574 ha, yang mengindikasikan kecukupan daya dukung lingkungan untuk membangun sistem pertanian berkelanjutan. Namun demikian, pada April-Mei nilai IDD $<1$ yang berarti ada keterbatasan pakan untuk mendukung populasi ternak yang ada. Berdasarkan nilai IDD bulanan, populasi sapi pembibitan yang dapat ditopang adalah 713 ekor dan sapi penggemukan sebanyak 24 ekor. Populasi sapi penggemukan dapat ditingkatkan hingga 1,590-2,515 ekor dengan menambah ketersediaan pakan melalui pembuatan silase, penanaman rumput gajah dan tanaman hijauan lain yang tahan kering.

Kata kunci: indeks ketersediaan pangan, daya dukung ekologis, penggemukan, pertanian berkelanjutan, sapi

\section{PENDAHULUAN}

Sistem pertanian terpadu tanaman-ternak populer diterapkan pada banyak negara (Garret et al., 2017; Carof dan

*Penulis untuk korespondensi. e-mail: edisang@gmail.com
Godinot, 2018; Harahap et al., 2019; Wiesner et al., 2020). Sistem tersebut mengoptimalkan limbah tanaman menjadi pakan ternak, dan kotoran ternak sebagai pupuk untuk meningkatkan kesuburan, siklus hara, dan produktivitas lahan (Reddy, 2016). Penerapan sistem dalam skala luas bahkan mampu mempercepat pengurangan kemiskinan 
dan gizi buruk, memperkuat keberlanjutan lingkungan, dan mengurangi pemanasan global (Munandar et al., 2014; Reddy, 2016; Wiesner et al., 2020).

Kajian integrasi tanaman-ternak pada level komunitas maupun kawasan di Indonesia, sudah banyak dilaporkan (Kariyasa, 2005; Diwyanto et al., 2007; Siswati dan Nizar, 2012; Handayanta et al., 2017; Sandi et al., 2018). Petani tertarik menerapkan sistem tersebut karena dapat mencegah erosi, mengurangi ketergantungan pupuk, dan meningkatkan manfaat lahan, produksi tanaman, populasi ternak, ketahanan pangan serta pendapatan (Mugnisjah et al., 2000; Kariyasa, 2005; Diwyanto et al., 2007; Salendu dan Elly, 2012; Yuliani, 2014; Carof dan Godinot, 2018; Harahap et al., 2019). Bahkan, menurut Sulistiyanto et al. (2016) dua ekor sapi dapat menghasilkan cukup biogas untuk memenuhi kebutuhan rumah tangga.

Persoalannya, sebagian ternak rakyat sering mengalami kekurangan pakan khususnya pada musim kemarau (Handayanta et al., 2017; Sandi et al., 2018) seperti pada Sekolah Peternakan Rakyat (SPR), sehingga keberlanjutan sistem menjadi terganggu. SPR adalah salah satu bentuk aksi komunitas yang bertujuan mendukung swasembada daging sapi (LPPM-IPB, 2015; Nuhung, 2015). Masalah tersebut menjadi dasar dilakukan kajian keberlanjutan pada penelitian ini. Pakan menjadi fokus karena tingkat ketersediaannya menjadi indikator utama daya dukung dan keberlanjutan usaha (Mukson et al., 2008; Sumarjono et al., 2008; Rinaldi et al., 2012; Rusnan et al., 2015; Jehemat et al., 2018; Naikofi et al., 2019).

Saat ini, jejak lahan (land footprint) merupakan salah satu bagian dari jejak lingkungan yang banyak digunakan untuk menilai keberlanjutan dan daya dukung usaha pertanian (Wiedmann dan Barrett, 2010; Bosire et al., 2015; Fischer et al., 2017; Arjuna dan Santosa, 2018; Santosa et al., 2018, Holmatov et al., 2019; Rotz et al., 2019). Jejak lahan dapat mencerminkan neraca kecukupan pangan dan pakan (Erb, 2004; Steen-Olsen et al., 2012; Weinzettel et al., 2013; Hoekstra dan Wiedmann, 2014). Menurut Erb (2004), jejak lahan umumnya ditelaah dari nilai jejak tanaman (cropland footprint) dan jejak peternakan (grazing land footprint). Penelitian bertujuan mengevaluasi daya dukung lingkungan sistem terpadu pertanian dan ternak melalui pendekatan jejak lahan dalam rangka membangun usaha pertanian terpadu berkelanjutan.

\section{BAHAN DAN METODE}

\section{Lokasi Studi}

Penelitian dilaksanakan pada Mei-Agustus 2019 di Sekolah Peternakan Rakyat (SPR) Mega Jaya Desa Sekaran (-7.0699313; 111.6612333), Kecamatan Kasiman, Kabupaten Bojonegoro, Provinsi Jawa Timur, Indonesia (Gambar 1). Desa Sekaran memiliki tiga dusun yakni Ngantru, Jarwetan dan Jarkulon yang terletak pada elevasi 82-124 m di atas permukaan laut (dpl). Data penduduk, ternak dan pertanian diperoleh dari statistik kecamatan (DPMD, 2018), dan data curah hujan diperoleh dari stasiun BMKG Tuban (http://dataonline.bmkg.go.id).

\section{Analisis Jejak Lahan}

Analisis jejak lahan pangan dan pakan mengikuti Erb (2004). Jejak lahan pangan dihitung dari luas lahan yang dibutuhkan untuk memenuhi konsumsi penduduk setara beras. Konsumsi pangan diperoleh dari hasil diskusi menggunakan pendekatan participatory rural appraisal (PRA) yang melibatkan 3 dusun. Jejak lahan pakan dihitung berdasarkan jumlah pakan untuk mendukung populasi dalam satuan ternak. Satuan ternak (ST) diperoleh dengan mengalikan jumlah ternak dengan 0.7 untuk sapi, dan 0.065 untuk kambing dan domba (Arief et al., 2017).

Lahan diasumsikan memiliki produktivitas sama (Fischer et al., 2017). Asumsi tersebut mengesampingkan variasi lingkungan dan teknologi yang digunakan oleh petani seperti jenis tanah, varietas, input pupuk, pestisida dan irigasi.

\section{Indeks Ketersediaan Pangan}

Indeks ketersediaan pangan (IKP) dihitung menurut Lestari et al. (2018) yang dimodifikasi menggunakan rasio swasembada. Rasio swasembada dihitung dari agregat produksi beras dibandingkan konsumsi. Rendemen beras diasumsikan 53\% dari gabah kering panen (GKP). Produktivitas padi sebesar 5.6 ton GKP ha ${ }^{-1}$ dan jagung 3.0 ton ha $^{-1}$ (DPMD, 2018). Produksi jagung tidak dipertimbangkan dalam penghitungan IKP karena $100 \%$ untuk dijual. IKP < 0.7 dinilai tidak tersedia, IKP 0.7-0.8 adalah rentan dan IKP $>0.8$ adalah tersedia.

$$
I K P=\frac{\text { Produksi beras }}{\text { Konsumsi beras }}
$$

IKP bulanan dihitung dari simulasi penyebaran stok panen bulanan dari Chafid (2007) untuk Kabupaten Demak, karena tidak tersedia data untuk kabupaten lain yang ada di Jawa Timur. Pada asumsi tersebut, sebaran stok pada 1, 2, 3, 4, 5, dan 6 bulan setelah panen jumlah berturut-turut adalah $50.20 \%, 37.79 \%, 26.16 \%, 23.59 \%, 18.53 \%$ dan $6.37 \%$. Susut gabah karena angkutan sebesar $1.43 \%$ dan susut simpan $0.53 \%$, serta benih dan pakan $0.75 \%$.

Konsumsi beras per kapita dihitung berdasarkan angka kecukupan gizi kelompok umur dari Peraturan Menteri

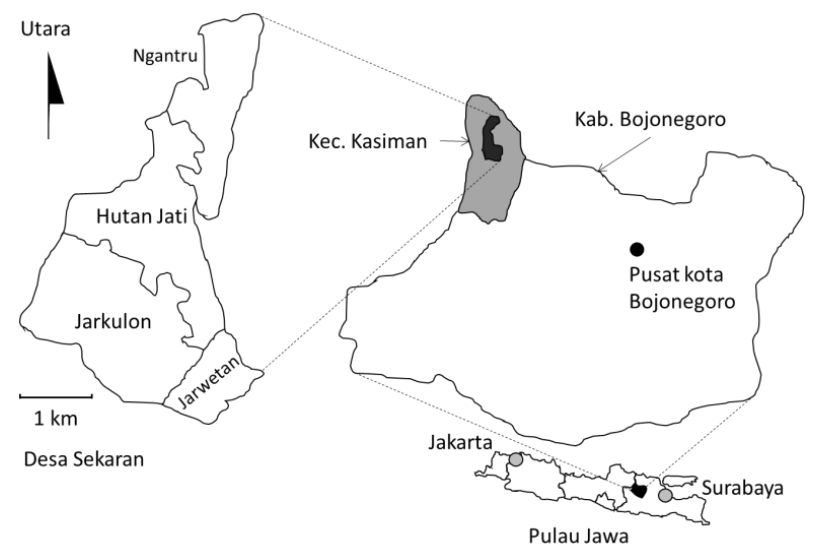

Gambar 1. Lokasi studi di Desa Sekaran, Kecamatan Kasiman, Kabupaten Bojonegoro, Jawa Timur 
Kesehatan (Permenkes, 2019), dengan asumsi seluruh karbohidrat diperoleh dari konsumsi beras. Secara ringkas, konsumsi beras per kapita per hari diperoleh dari kebutuhan karbohidrat setiap kelompok umur dengan asumsi hanya berasal dari beras. Jumlah konsumsi tersebut lalu dikalikan dengan jumlah penduduk dari masing-masing kelompok umur, dan dikalikan dengan jumlah hari dalam setahun (365 hari) untuk memperoleh angka konsumsi per kapita per tahun per kelompok umur. Rata-rata konsumsi per kapita dihitung dari total konsumsi dari seluruh kelompok umur dibagi dengan jumlah penduduk.

\section{Indeks Daya Dukung Pakan}

Potensi pakan dihitung dari limbah pertanian dan hijauan dalam bentuk bahan kering (BK). Potensi pakan setiap agroekologi diperoleh dari referensi (Afrizal et al., 2014; Tiwow et al., 2016; Arief et al., 2017). Daya dukung pakan (DD) dihitung berdasarkan konsumsi bahan kering (BK) per satuan ternak (ST) mengikuti Sumanto dan Juarini (2006). Perhitungan mencakup skenario ternak eksisting, dan ternak SPR dengan asumsi populasi 1,000 ekor betina produktif dan 100 ekor pejantan (LPPM-IPB, 2015) atau $770 \mathrm{ST}$.

$$
D D=\frac{\text { Produksi bahan kering }}{\text { Konsumsi BK/ST } / \text { Tahun }}
$$

Indeks daya dukung pakan (IDD) dihitung mengikuti Ashari et al. (1999) yakni konsumsi pakan sebanyak 9.1 $\mathrm{kg} \mathrm{BK}$ hari $^{-1} \mathrm{ST}^{-1}$ atau setara 3 ton $\mathrm{BK}$ tahun $^{-1} \mathrm{ST}^{-1}$. IDD dinilai sangat kritis, kritis, rawan dan aman dengan nilai berturut-turut $<1$ (kurang pakan), >1-1.5 (sangat rawan), $>1.5-2$ (rawan), dan $>2$ (cukup). IDD bulanan dihitung berdasarkan potensi pakan bulanan dengan membagi nilai tahunan dengan 12 bulan.

$$
I D D=\frac{\text { Total produksi BK }}{\text { Jumlah populasi } x \text { Konsumsi BK/ST /Tahun }}
$$

\section{HASIL DAN PEMBAHASAN}

\section{Profil Lokasi Studi}

Desa Sekaran termasuk daerah kering dengan 4-6 bulan basah dan 5-6 bulan kering. Musim hujan umumnya mulai November-Mei dan musim kering terjadi pada JuniOktober (Gambar 2). Curah hujan rata-rata tahunan adalah 819.3-1,320.1 mm.

Desa Sekaran memiliki 1,189 kepala keluarga (KK) dengan total 4,198 jiwa. Mata pencaharian utama penduduk adalah pertanian, diikuti peternakan dan buruh harian. KK yang memiliki lahan sebanyak $67.12 \%$, dengan $525 \mathrm{KK}$ (65.87\%) memiliki lahan $<1$ ha, diikuti $260 \mathrm{KK}(32.62 \%)$ memiliki lahan $1-5$ ha dan 12 KK (1.51\%) memiliki lahan lebih dari 5 ha (Tabel 1). Sebanyak 56.96\% KK merupakan keluarga Sejahtera-1 diikuti dengan Prasejahtera (18.37\%) dan Sejahtera-2 (18.20\%). Jumlah peternak sebanyak $804 \mathrm{KK}$ terdiri $523 \mathrm{KK}$ memelihara total 1041 ekor sapi, 67 KK memelihara total 102 ekor kambing, dan 214 KK memelihara total 316 ekor domba. Jenis sapi umumnya Peranakan Ongole (PO) dan Brahman Cross. Ternak ayam rakyat dan perusahaan juga ditemukan pada lokasi, tetapi tidak diperhitungkan dalam analisis.

Lokasi studi memiliki luas wilayah 1,690 ha yang terdiri atas lahan sawah dan lahan kering (Tabel 2). Seluas 412 ha dari 447 ha sawah merupakan tadah hujan dan 35 ha merupakan irigasi setengah teknis. Pada musim hujan, komoditas yang diusahakan adalah padi (50.77\%) dan jagung (42.02\%). Pola tanam sawah tadah hujan yang ada di Dusun Ngantru dan Jarkulon adalah padi-padi-jagung (20\%), padi-jagung-kacang tanah/kacang tunggak $(60 \%)$, dan padi-jagung-bera (20\%). Sebagian petani menanam kacang tanah/kacang tunggak pada akhir musim hujan, dan ada petani menanam tebu seluas 10 ha. Sawah irigasi di Dusun Jarwetan memiliki pola tanam padi-padi-jagung/

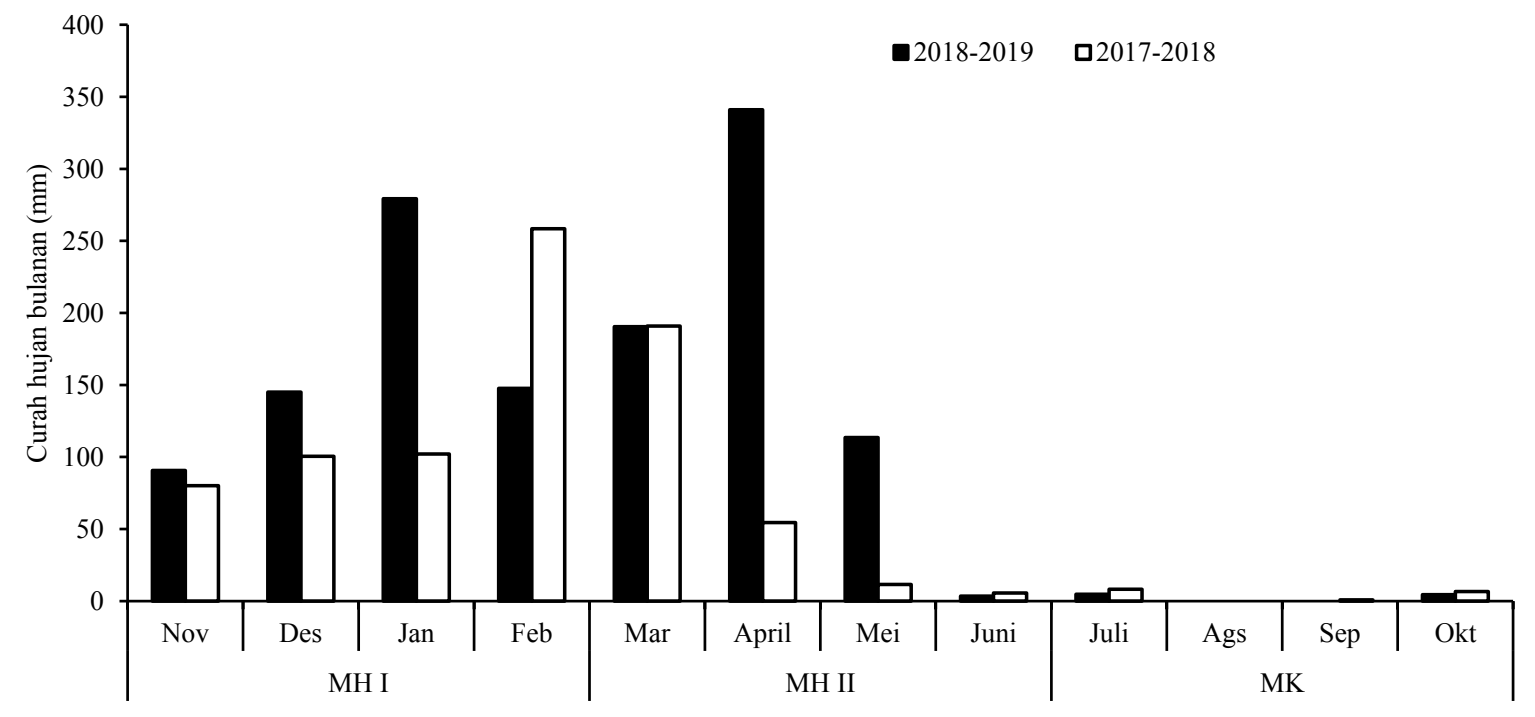

Gambar 2. Sebaran curah hujan bulanan 2017-2019 di lokasi studi. Data berasal dari stasiun BMKG Tuban 
Tabel 1. Jumlah dan persentase rumah tangga berdasarkan kepemilikan dan luas lahan, dan kesejahteraan di Desa Sekaran, Kecamatan Kasiman, Kabupaten Bojonegoro Tahun 2019

\begin{tabular}{llcc}
\hline Peubah & \multicolumn{1}{c}{ Kriteria } & Jumlah rumah tangga & $\%$ \\
\hline Lahan pertanian (KK) & Memiliki & 798 & 67.12 \\
& Tidak memiliki & 391 & 32.88 \\
Sebaran lahan (KK) & $<1$ ha & 525 & 65.87 \\
& $1-5$ ha & 260 & 32.62 \\
& $6-10$ ha & 12 & 1.51 \\
Kesejahteraan (KK) & Prasejahtera & 219 & 18.37 \\
& Sejahtera 1 & 679 & 56.96 \\
& Sejahtera 2 & 217 & 18.20 \\
& Sejahtera 3 & 77 & 6.46 \\
\hline
\end{tabular}

Keterangan: DPMD (2018)

Tabel 2. Ketersediaan dan pola tanam di Desa Sekaran, Kecamatan Kasiman, Kabupaten Bojonegoro Tahun 2019

\begin{tabular}{|c|c|c|c|c|c|}
\hline \multirow{2}{*}{ Jenis lahan } & \multirow{2}{*}{ Kriteria } & \multirow{2}{*}{ Luas (ha) } & \multicolumn{3}{|c|}{ Pola tanam } \\
\hline & & & MH I & MH II & MK \\
\hline \multirow[t]{2}{*}{ Sawah } & Irigasi $1 / 2$ teknis & 35 & Padi & Padi & Jagung/Tembakau \\
\hline & Tadah hujan & 412 & Padi & Jagung & Kacang tanah/tunggak \\
\hline \multirow[t]{6}{*}{ Lahan kering } & Tegal/ladang & 330 & Jagung & Jagung & Kacang tanah/Bera \\
\hline & Pemukiman & 70 & - & - & - \\
\hline & Fasum & 46 & - & - & - \\
\hline & Pekarangan & 40 & Campuran & Campuran & Campuran \\
\hline & Hutan jati & 757 & TS Jagung & TS Jagung & Bera \\
\hline & Total & 1,690 & - & - & - \\
\hline
\end{tabular}

Keterangan: MH-musim hujan, MK-musim kering. MH I: Nov-Feb, MH II: Mar-Juni, MK: Jul-Okt

tembakau; tembakau ditanam selama musim kemarau. Tegal atau ladang yang luas di Dusun Ngantru dan Jarkulon, umumnya ditanami jagung-jagung-bera.

Lokasi studi bersinggungan dengan areal hutan jati Perhutani KPH Cepu. Dari 757 ha hutan jati dengan usia pohon $>5$ tahun, sebanyak 87 ha dikerjasamakan dengan petani untuk tanaman jagung tumpangsari. Setiap petani mengelola lahan 1-2 ha dengan pola tanam jagung-jagungbera atau jagung-bera-bera. Sebagian petani menanam rumput gajah di antara barisan pohon jati untuk pakan ternak dan menahan erosi. Saat musim kering, areal tumpangsari diberakan dan sebagian peternak menggembalakan sapi di lokasi hutan jati tersebut.

\section{Neraca Pangan}

Beras merupakan pangan pokok penduduk Desa Sekaran. Rata-rata konsumsi per tahun per kapita adalah $98.55 \mathrm{~kg}$ setara beras dengan total 413.7 ton per tahun atau 34.5 ton per bulan. Nilai tersebut diperoleh dari simulasi kebutuhan karbohidrat setara beras berdasarkan kelompok umur menurut Permenkes (Permenkes, 2019).
Produksi beras adalah 1,392.1 ton (Tabel 3). Produksi jagung sebanyak 3,738.0 ton, tetapi karena seluruhnya dijual maka tidak diperhitungkan dalam IKP. Berdasarkan produksi beras, nilai IKP tahunan sebesar 3.4 atau termasuk aman. Tetapi nilai IKP bulanan bervariasi antara katagori rawan pangan hingga aman tergantung ketersediaan beras. Sekitar 80\% luas panen padi terjadi pada MH I, dan puncak panen jagung terjadi pada MH II. IKP berada pada nilai aman sejak panen MH I (Februari-Maret) hingga MH II (Juni-Juli), dan nilai IKP $<0.7$ atau rawan pangan terjadi pada September-Januari (Gambar 3). Pada bulan tersebut, sebagian besar penduduk membeli beras dari luar desa, yang bertepatan dengan musim kering (Gambar 2).

\section{Neraca Pakan}

Jumlah seluruh ternak (kambing, domba dan sapi) setara dengan 755.9 ST (Tabel 4). Jumlah pakan setempat mencukupi dengan IDD=7.2 atau aman. Secara akumulatif, setiap tahun tersedia 5,424.73 ton bahan kering yang mampu mendukung 1,808.2 ST atau setara untuk 2,583 ekor sapi. Pakan tersebut $79.71 \%$ berasal dari limbah pertanian, 
Tabel 3. Luas panen, indeks ketersediaan pangan (IKP) dan surplus pangan di Desa Sekaran, Kecamatan Kasiman, Kabupaten Bojonegoro tahun 2019

\begin{tabular}{lccccc}
\hline Komoditas & $\begin{array}{c}\text { Luas panen } \\
\text { (ha per tahun) }\end{array}$ & $\begin{array}{c}\text { Produktivitas } \\
\left.\text { (ton GKP ha }^{-1}\right)\end{array}$ & $\begin{array}{c}\text { Produksi tersedia } \\
\text { (ton per tahun) }\end{array}$ & IKP & $\begin{array}{c}\text { Surplus } \\
\text { (ton) }\end{array}$ \\
\hline Jagung & 1,246 & 3.2 & $3,738.0$ & - $^{\text {y }}$ & $3,738.0$ \\
Padi & 482 & 5.6 & $1,392.1$ & 3.4 & 978.4 \\
\hline
\end{tabular}

Keterangan: ${ }^{\mathrm{K}}$ Konversi GKP ke beras 53\%, setelah koreksi Chafid (2007); ${ }^{\mathrm{y}}$ Tidak tersedia karena seluruhnya dijual

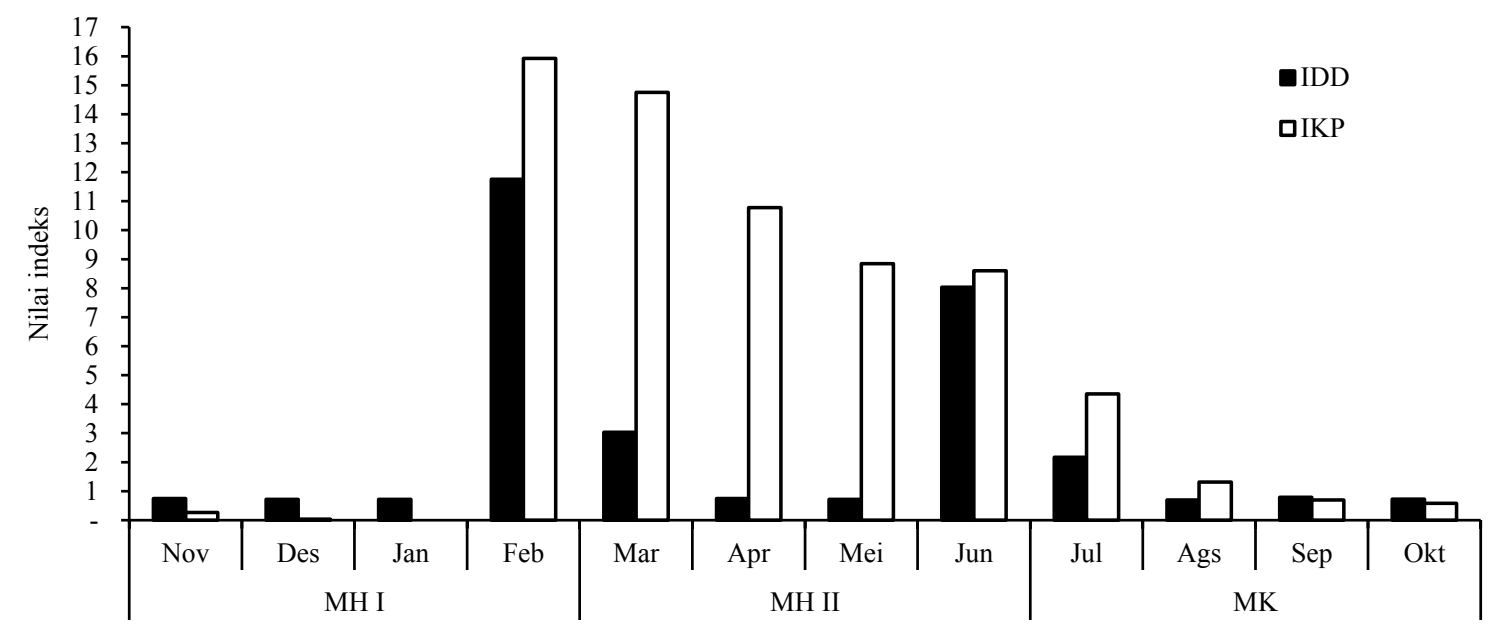

Gambar 3. Indeks ketersediaan pangan (IKP) dan indeks daya dukung pakan (IDD) bulanan di Desa Sekaran, Kecamatan Kasiman, Kabupaten Bojonegoro

Tabel 4. Luas panen, potensi bahan kering, daya dukung, populasi dan potensi tambah ternak di Desa Sekaran, Kecamatan Kasiman, Kabupaten Bojonegoro tahun 2019

\begin{tabular}{|c|c|c|c|c|c|c|c|c|}
\hline \multirow{2}{*}{ Sumber } & \multirow{2}{*}{$\begin{array}{l}\text { LPT } \\
\text { (ha) }\end{array}$} & \multicolumn{3}{|c|}{ Produksi bahan kering (ton) } & \multirow{2}{*}{$\begin{array}{c}\text { DD } \\
(\mathrm{ST})^{\mathrm{x}}\end{array}$} & \multirow{2}{*}{ IDD } & \multirow{2}{*}{$\begin{array}{c}\text { PT } \\
(\mathrm{ST})^{\mathrm{w}}\end{array}$} & \multirow{2}{*}{$\begin{array}{c}\mathrm{TT} \\
(\mathrm{ST})^{*}\end{array}$} \\
\hline & & Per haz & $\mathrm{TP}(\%)^{\mathrm{y}}$ & Total & & & & \\
\hline \multicolumn{9}{|l|}{ Limbah } \\
\hline Jagung & 1,246 & 3.10 & 60 & $2,314.57$ & 771.5 & 3.1 & & \\
\hline Padi & 482 & 6.57 & 60 & $1,900.04$ & 633.3 & 2.5 & & \\
\hline Tebu & 10 & 4.00 & 42 & 16.80 & 5.6 & 0.0 & & \\
\hline Kacang $^{v}$ & 82.4 & 2.50 & 45 & 92.70 & 30.9 & 0.1 & & \\
\hline \multicolumn{9}{|l|}{ Hijauan } \\
\hline Pekarangan & 40 & 1.03 & 50 & 20.60 & 6.9 & 0.0 & & \\
\hline Sawah & 447 & 1.44 & 50 & 321.84 & 107.3 & 0.4 & & \\
\hline Tegal/Ladang & 330 & 2.88 & 50 & 475.20 & 158.4 & 0.6 & & \\
\hline Bera/fasum & 38.8 & 2.88 & 50 & 55.87 & 18.6 & 0.1 & & \\
\hline Hutan jati ${ }^{u}$ & 757 & 0.60 & 50 & 227.10 & 75.7 & 0.3 & & \\
\hline \multicolumn{4}{|c|}{ Total } & $5,424.73$ & $1,808.2$ & 7.2 & 755.9 & 1,052 \\
\hline
\end{tabular}

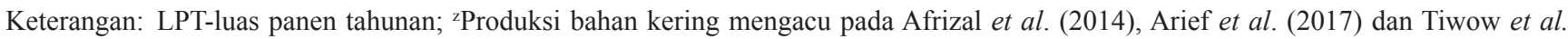

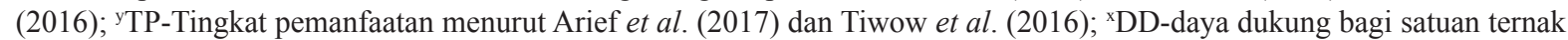
(ST); " PT-populasi ternak total; "Kacang tanah dan kacang tunggak; " Termasuk tumpangsari 87 ha; IDD-indeks daya dukung; *TT-tambah ternak 
dan sisanya berasal dari hijauan rumput alam dan rumput gajah. Berdasarkan potensi pakan tahunan, ketersediaannya mampu menampung tambahan 1,052 ST setara dengan 1,502 ekor sapi.

Namun demikian, terdapat fluktuasi IDD bulanan yang mencerminkan adanya periode kurang ketersediaan pakan setempat (IDD < 1) (Gambar 3). Kekurangan pakan terjadi pada Agustus-Desember dan April-Mei, sebaliknya terjadi kelebihan pakan Januari-Maret dan Juni-Juli. Fluktuasi tersebut sejalan dengan musim kemarau dan periode antar panen tanaman pangan. Menurut Handayanta et al. (2017) peternak rakyat umumnya menghadapi kesulitan memperoleh pakan alami musim kemarau. Hal yang sama juga dihadapi oleh peternak di Desa Sekaran. Lebih dari 70\% peternak di Desa Sekaran memelihara sapi untuk mendapatkan anak sapi (pembibitan) dan sisanya untuk penggemukan (fattening). Lebih dari $90 \%$ populasi ternak dipelihara dalam kandang secara intensif. Kedua fakta tersebut menunjukkan pentingnya kontinuitas penyediaan pakan di lokasi studi.

\section{Jejak Lahan}

Jejak lahan pangan tahunan adalah 143.2 ha setara luas panen sawah (Tabel 5). Bila dibagi per kapita, jejak tahunan lahan pangan $341.1 \mathrm{~m}^{2}$ orang $^{-1}$. Dibandingkan dengan total luas sawah yang tersedia yakni 447 ha (Tabel 2), maka ketersediaan areal sawah mampu mendukung kecukupan pangan. Berdasarkan simulasi, untuk mendukung kecukupan pangan berkelanjutan maka setiap bulan diperlukan luas panen padi 11.9-12.2 ha. Angka tersebut merupakan acuan lahan sawah yang perlu berproduksi secara berlanjutan setiap bulan.

Jejak lahan pakan ternak untuk populasi ternak eksisting sebesar 759.1 ha dengan rincian: 143.2 ha berupa luas panen lahan sawah untuk menghasilkan jerami dan 615.9 ha berupa luas hijauan (Tabel 5). Pada skenario SPR1111 (LPPM-IPB, 2015), jejak lahan ternak adalah sebesar 799.5 ha atau membutuhkan tambahan 40.3 ha lahan hijauan. Perbedaan jejak lahan antara populasi eksisting dengan SPR1111 disebabkan adanya penambahan 42.2 ST pada skenario SPR-1111. Kedua sekenario tersebut dapat diterapkan di Desa Sekaran karena luas lahan potensial pengembangan pakan mencapai 817 ha (Tabel 2). Dengan kata lain, daya dukung lingkungan memadai untuk pengembangan usaha peternakan sesuai populasi ternak saat ini maupun skenario SPR-1111.
Secara konsolidasi, nilai jejak lahan total pangan-pakan yakni 759.1 ha yang didalamnya telah mencakup luas lahan untuk produksi pangan khususnya beras, dan pakan hijauan. Total jejak lahan tersebut lebih kecil daripada luas lahan tersedia untuk kegiatan agronomi yakni 1,574 ha, termasuk areal hutan jati. Luas lahan kegiatan agronomi adalah total luas lahan lokasi studi (Tabel 2) dikurangi peruntukan bagi pemukiman dan fasilitas umum (fasum) seperti jalan raya, areal makam, sekolah, ibadah, pasar, perkantoran dan sebagainya. Selisih luasan lahan merupakan areal potensial untuk pengembangan pakan. Dengan demikian, lokasi studi memiliki daya dukung lingkungan yang memadai untuk pengembangan pertanian berkelanjutan.

\section{Implikasi bagi Strategi Pengembangan}

Penelitian mengungkap bahwa pada level desa, pengusahaan tanaman pangan telah terintegrasi dengan penyediaan pakan, berdasarkan kriteria yang telah dikemukakan oleh peneliti lain (Yuliani, 2014; Carof dan Godinot, 2018; Harahap et al., 2019). Namun pada level keluarga, terdapat $32.9 \% \mathrm{KK}$ yang tidak memiliki lahan (Tabel 1), dan KK tersebut diduga memenuhi kebutuhan pangan termasuk beras dengan cara membeli. Di sisi lain, dari $804 \mathrm{KK}$ pemilik ternak, terdapat $6 \mathrm{KK}$ atau $0.8 \%$ yang tidak memiliki lahan dan menggantungkan penyediaan pakan dari pihak lain. Fakta tersebut menunjukkan angka ketergantungan pangan rumah tangga di Desa Sekaran terhadap pasokan pangan dari petani lain atau dari pasar termasuk cukup tinggi. Kondisi kecukupan pangan berbanding terbalik dengan kecukupan pakan untuk peternakan, yang sebagian besar dapat dipenuhi dari petani sendiri.

Walaupun tingkat ketergantungan pakan ternak relatif rendah, namun perlu diperhatikan karena secara agregat ada bulan-bulan defisit pakan bagi sebagian besar peternak yang mengusahakan pembibitan sapi (Gambar 3). Menurut Handayanta et al. (2016) payback cost pembibitan sapi adalah 4.3 tahun. Para peternak di Desa Sekaran mengatasi kelangkaan pakan pada Agustus-Desember dan April-Mei dengan menyediakan pakan konsentrat/dedak, dan hijauan daun pisang, nangka, akasia dan lamtoro. Sebagian lain mendatangkan jerami dari wilayah sekitar seperti Kabupaten Nganjuk, Ngawi dan Madiun yang merupakan daerah sawah irigasi teknis. Konsekuensinya, biaya pakan menjadi relatif mahal. Kajian Bahruddin (2018) di Desa Sekaran menunjukkan bahwa biaya pakan hampir $80 \%$ dari total

Tabel 5. Jejak lahan pangan dan ternak dua skenario populasi ternak di Desa Sekaran Kecamatan Kasiman Kabupaten Bojonegoro

\begin{tabular}{lccc}
\hline Populasi ternak & Jejak lahan pangan $(\text { ha })^{\mathrm{x}}$ & Jejak lahan hijauan (ha) $^{\mathrm{w}}$ & Total jejak lahan ternak (ha) $^{\mathrm{y}}$ \\
\hline Eksisting $^{\mathrm{z}}$ & 143.2 & 615.9 & 759.1 \\
SPR-1111 $^{\mathrm{y}}$ & 143.2 & 656.3 & 799.5 \\
\hline
\end{tabular}

Keterangan: ${ }^{z} 1041$ ekor sapi +102 ekor kambing +316 ekor domba; ${ }^{y} 100$ ekor sapi +102 ekor kambing +316 ekor domba; ${ }^{x}$ Asumsi produktivitas jerami padi dimanfaatkan 3.85 ton $\mathrm{BK} \mathrm{ha}^{-1}$; wPoduktivitas hijauan dimanfaatkan 3.14 ton $\mathrm{BK}^{-1}$ per tahun 
biaya pemeliharaan. Di Gunung Kidul-DIY, Handayanta et al. (2017) menghitung biaya pakan mencapai Rp 46,167 $\mathrm{kg}^{-1}$ bobot sapi.

Untuk menekan biaya pakan, perlu pengaturan dua hal yakni populasi untuk usaha pembibitan maupun penggemukan, dan penyediaan pakan. Gambar 3 menunjukkan bahwa nilai IDD terendah pada Agustus yakni 0.70. Nilai tersebut mampu untuk mendukung 526.6 ST; jika dikurangi populasi kambing dan domba saat ini 27.2 ST, maka populasi sapinya 499.4 ST setara 713 ekor sapi. Populasi sapi tersebut tepat untuk usaha pembibitan tanpa perlu intervensi pakan.

Sebaliknya, pada Februari-Juli terjadi kelebihan pakan (Gambar 3), yang tepat untuk usaha penggemukan sapi. Ada tiga skenario populasi penggemukan yakni tanpa intervensi pakan, intervensi rendah, dan intervensi tinggi dengan populasi berturut-turut 24, 1,590, dan 2,515 ekor; dengan asumsi satu ekor sapi membutuhkan $6.37 \mathrm{~kg}$ BK hari $^{-1}$ (Ashari et al., 1999). Pada intervensi pakan rendah diperlukan tambahan pakan untuk April dan Mei sebesar 294.3 dan 309.2 ton, sedangkan untuk intervensi tinggi diperlukan tambahan pakan untuk April, Mei dan Juli masing-masing sebesar 471.1, 491.9, dan 182.7 ton BK. Tambahan pakan pada Juli lebih rendah daripada Apil dan Mei karena tersedia jerami padi dari panen MH II.

Intervensi penyediaan pakan dapat menggunakan silase, rumput, limbah atau hijauan. Silase dapat dibuat menggunakan jerami padi dan jagung yang surplus 6,304.5 ton pada Februari-Maret. Penanaman rumput gajah dapat dilakukan dengan kerjasama Perhutani di hutan jati secara tumpangsari dengan tujuan tambahan sebagai pencegah erosi. Menurut Seseray et al. (2013) rumput gajah mampu berproduksi per bulan 5.2 ton $\mathrm{BK} \mathrm{ha}^{-1}$. Luas panen rumput gajah untuk intervensi rendah adalah 67-60 ha dan untuk intervensi tinggi seluas 91-95 ha.

Limbah tanaman atau hijauan non rumput dapat ditingkatkan dengan cara menanam tanaman tahan kering menggunakan sistem lorong (hedge-row). Tanaman yang direkomendasikan adalah gamal (Gliricidia sepium), indigofera (Indigofera zollingeriana), kaliandra (Calliandra callothyrsus Meisen), lamtoro (Leucaena leucocephala), flemingia (Flemingia congesta), dan turi (Sesbania grandiflora) serta kaktus gepeng (Opuntia ficus-indica) (Matheus, 2010; Herdiawan et al., 2012; Reis et al., 2018).

Selain itu, juga perlu mengembangkan tanaman pangan yang sebagian besar telah ada dan umum dibudidayakan petani di lokasi studi seperti pisang, nangka, sorgum, talas, belitung, dan suweg. Tanaman tersebut selain menghasilkan hijauan juga dapat dimanfaatkan sebagai tambahan pangan, diantaranya melalui optimalisasi pemanfaatan pekarangan dan intensifikasi lahan pertanian yang ada. Usaha budidaya tanaman di lokasi studi utamanya adalah pertanian lahan kering. Terkait hal tersebut, Matheus et al. (2017) menyarankan untuk memanen air hujan guna mendukung optimalisasi lahan kering untuk mendukung diversifikasi tanaman. Dalam rangka mendukung upaya diversifikasi tanaman sumber pangan dan pakan, perlu dilakukan kajian faktor-faktor agronomi untuk membuat estimasi produksi (Irfanda dan Santosa, 2016) dan menentukan luas areal optimum masing-masing komoditas yang direkomendasikan.

\section{KESIMPULAN}

Daya dukung ekologis Desa Sekaran mampu mendukung pengembangan pertanian terpadu tanamanternak seperti ditunjukkan oleh nilai indeks ketersediaan pangan $(\mathrm{IKP}=3.4)$ dan indeks daya dukung pakan (IDD = 7.2). Selain itu, nilai jejak lahan total pada sistem pertanian terpadu untuk mendukung pangan dan pakan sebesar 759.1 ha atau lebih kecil dari luas lahan yang tersedia. Dalam setahun, daya dukung pakan bulanan terendah ada pada bulan Agustus sebesar 0.7, dan angka tersebut dapat menjadi acuan dalam menetapkan populasi maksimum usaha pembibitan dan penggemukan sapi, serta manajemen pakan. Populasi sapi pembibitan maksimum adalah 713 ekor, sedangkan populasi penggemukan sapi 24-2,515 ekor tergantung skenario pengelolaan pakan.

\section{UCAPAN TERIMA KASIH}

Ucapan terima kasih disampaikan kepada Kemenistek/ BRIN yang telah membiayai penelitian skema PTUPT tahun 2019-2020, dan kepada Muhammad Tajuddin, SP yang membantu penelitian. Terima kasih kepada Pimpinan SPR Megajaya khususnya Bapak Darwanto.

\section{DAFTAR PUSTAKA}

Afrizal, R. Sutrisna, Muhtarudin. 2014. Potensi hijauan sebagai pakan ruminansia di Kecamatan Bumi Agung Kabupaten Lampung Timur. J. Ilmiah Peternakan Terpadu 2:93-100.

Arief, H., L. Khaerani, R.Z. Islami. 2017. Peta potensi kawasan peternakan berbasis daya dukung lokal di Jawa Barat. hal 835-847. Dalam Prosiding Seminar Nasional Agroinovasi Spesifik Lokasi untuk Ketahanan Pangan Era Masyarakat Ekonomi ASEAN. Tersedia:http://lampung.litbang.pertanian. go.id/ind/images/stories/publikasi/ Prosiding_2_ 2017/04.Renisi-131-HasniArief.pdf.

Arjuna, R.T., E. Santosa. 2018. Asesmen carbon footprint pada produksi minyak kelapa sawit (Elaeis guineensis Jacq.) di Kebun Sei Lukut, Kabupaten Siak, Riau. Bul. Agrohorti 6:287-295.

Ashari, B. Wibowo, E. Juarini, Sumanto, A. Nurhadi, Soeripto, Suratman, A Rukanda. 1999. Nisbah Pertumbuhan Daerah atau Location Quotient untuk Peternakan. Balai Penelitian Ternak dan Direktorat Bina Penyebaran dan Pengembangan Peternakan. Jakarta, ID. 
Bahruddin, A. 2018. Analisis Pendapatan Usaha Ternak Sapi Sekolah Peternakan Rakyat Mega Jaya. Skripsi. Institut Pertanian Bogor, Bogor.

Bosire, C.K., J.O. Ogutu, M.Y. Said, M.S. Krol, J. de Leeuw, A.Y. Hoekstra. 2015. Trends and spatial variation in water and land footprints of meat and milk production systems in Kenya. Agric. Ecosyst. Environ. 205:3647.

Carof, M., O. Godinot. 2018. Survey data from 38 integrated crop-livestock farming systems in Western France. Data in Brief 18:723-726.

Chafid, M. 2007. Alternatif model pendugaan stok gabah/ beras di rumah tangga petani. Informatika Pert. 16: 999-1018.

Diwyanto, K., A. Priyanti, R.A. Saptati. 2007. Prospek pengembangan usaha peternakan pola integrasi. Sains Peternakan 5:26-33.

DPMD [Dinas Pemberdayaan Masyarakat dan Desa]. 2018. Daftar Isian Potensi dan Tingkat Perkembangan Desa. Kabupaten Bojonegoro. Indonesia, ID.

Erb, K-H. 2004. Actual land demand of Austria 1926-2000: A variation on ecological footprint assessments. Land Use Policy 21:247-259.

Fischer, G., S. Tramberend, H. van Velthuizen, S. Wunder, T. Kaphengst, K. McFarland, M. Bruckner, S. Giljum. 2017. Extending Land Footprints Towards Characterizing Sustainability of Land Use. TEXTE 79/2017. http://www.umweltbundesamt.de/ publikationen [10 April 2020].

Garrett, R.D., M. Niles, J. Gil, P. Dy, J. Reis, J. Valentim. 2017. Policies for reintegrating crop and livestock systems: A comparative analysis. Sustainability 9: 473-495.

Handayanta, E., Lutojo, K. Nurdiati. 2017. Efisiensi produksi sapi potong pada peternakan rakyat pada musim kemarau di daerah pertanian lahan kering Kabupaten Gunungkidul. Caraka Tani 32:49-54.

Harahap, K.Z., Iskandarini, S.N. Lubis. 2019. Analisis dampak program sistem integrasi padi dan ternak (SIPT). J. Soc. Econ. Agric. Agribusiness 10:41-55.

Herdiawan, I., L. Abdullah, D. Sopandie, P.D.M.H. Karti, N. Hidayati. 2012. Karakteristik morfologi tanaman pakan Indigofera zollingeriana pada berbagai taraf stres kekeringan dan interval pemangkasan. JITV 17: 276-283.
Hoekstra, A.Y., T.O. Wiedmann. 2014. Humanity's unsustainable environmental footprint. Science 344: 1114-7.

Holmatov, B., A.Y. Hoekstra, M.S. Krol. 2019. Land, water and carbon footprints of circular bioenergy production systems. Renew. Sust. Energy Rev. 111:224-235.

Irfanda, M., E. Santosa. 2016. Peramalan produksi kelapa sawit (Elaeis guineensis Jacq.) di Perkebunan Sei Air Hitam berdasarkan kajian faktor agroekologi. Bul. Agrohort 4:282-287.

Jehemat, A., D. Kantur, F. Ranta. 2018. Daya dukung limbah pertanian terhadap ketersediaan pakan ternak dalam penerapan sistem pertanian terpadu berbasis tanaman dan ternak sapi di Desa Fatuknutu Kecamatan Amabi Oefeto Kabupaten Kupang. Partner 23:601-610.

Kariyasa, K. 2005. Sistem integrasi tanaman-ternak dalam perspektif reorientasi kebijakan subsidi pupuk dan peningkatan pendapatan petani. Analisis Kebijakan Pert. 3:68-80.

Lestari, A.A.A., D. Martianto, I. Tanziha. 2018. Pengembangan indeks ketahanan pangan dan gizi tingkat Kabupaten di Kabupaten Bandung Barat. J. Ekon. Pert. Agribisnis 2:62-76.

LPPM-IPB [Lembaga Penelitian dan Pengabdian kepada Masyarakat-Institut Pertanian Bogor]. 2015. Buku Panduan Sekolah Peternakan Rakyat (SPR-1111). LPPM-IPB Bogor. Indonesia, ID.

Matheus, R., M. Basri, M.S. Rompon, N. Neonufa. 2017. Strategi pengelolaan pertanian lahan kering dalam meningkatkan ketahanan pangan di Nusa Tenggara Timur. Partner 22:529-541.

Matheus, R. 2010. Kajian peranan tanaman hedgerow dalam sistem usahatani konservasi di lahan kering terhadap sifat fisik tanah. Partner 17:61-66.

Mugnisjah, W.Q., Suwarto, A.S. Solihin. 2000. Agribisnis terpadu bersistem LEISA di lahan basah: Model hipotetik. J. Agron. Indonesia 28:49-61.

Munandar, F. Gustiar, Yakup, R. Hayati. 2014. Sistem pertanian terpadu biocyclofarming sebagai alternatif teknologi budidaya pertanian rendah emisi gas rumah kaca untuk mitigasi dampak perubahan iklim global. Buana Sains 14:131-139.

Naikofi, I., N. Wijayanto, A.M. Fuah. 2019. Daya dukung silvopastur di Kecamatan Insana Kabupaten Timor Tengah Utara, Nusa Tenggara Timur. J. Ilmu Prod. Teknol. Hasil Peternakan 7:62-66. 
Nuhung, I.A. 2015. Kinerja, kendala, dan strategi pencapaian swasembada daging sapi. Forum Penel. Agro Ekon. 33:63-80.

[Permenkes] Peraturan Menteri Kesehatan Republik Indonesia. 2019. Peraturan Menteri Kesehatan Republik Indonesia Nomor 28 Tahun 2019 Tentang Angka Kecukupan Gizi Yang Dianjurkan Untuk Masyarakat Indonesia. http://hukor.kemkes.go.id/ uploads/produk_hukum/PMK_No_28_Th_2019 [16 April 2020].

Reddy, P.P. 2016. Integrated crop-livestock farming systems. pp 357-370. In: Sustainable Intensification of Crop Production. Springer, Singapore. Doi:10.1007/978-981-10-2702-4_23.

Reis, C.M.G., L.C. Gazarini, T.F. Fonseca, M.M. Ribeiro. 2018. Above-ground biomass estimation of Opuntia ficus-indica (L.) Mill. for forage crop in a Mediterranean environment by using nondestructive methods. Exp. Agric. 54:227-242.

Rotz, A., S. Asem-Hiablie, S. Place, G. Thoma. 2019. Environmental footprints of beef cattle production in the United States. Agric. Syst. 169:1-13.

Salendu, A.H.S., F.H. Elly. 2012. Pemanfaatan lahan di bawah pohon kelapa untuk hijauan pakan sapi di Sulawesi Utara. Trop. Anim. Health Prod. 45:13691374.

Sandi, S., M. Desiarni, Asmak. 2018. Manajemen pakan ternak sapi potong di peternakan rakyat di Desa Sejaro Sakti Kecamatan Indralaya Kabupaten Ogan Ilir. J. Peternakan Sriwijaya 7:21-29.

Santosa, E., I.M. Stefano, A.G. Tarigan, A. Wachjar, S. Zaman, H. Agusta. 2018. Tree-based water footprint assessment on established oil palm plantation in North Sumatera, Indonesia. J. Agron. Indonesia 46: 111-118.

Seseray, D.Y., B. Santoso, M.N. Lekitoo. 2013. Produksi rumput gajah (Pennisetum purpureum) yang diberi pupuk N, P dan K dengan dosis 0, 50 dan 100\% pada defoliasi hari ke-45. Sains Peternakan 11:49-55.
Siswati, L., R. Nizar. 2012. Model pertanian terpadu tanaman hortikultura dan ternak sapi untuk meningkatkan pendapatan petani. J. Peternakan Indonesia 14:379384.

Steen-Olsen, K., J. Weinzettel, G. Cranston, A.E. Ercin, E.G. Hertwich. 2012. Carbon, land, and water footprint accounts for the European Union: Consumption, production, and displacements through international trade. Environ. Sci. Technol. 46:10883-91.

Sulistiyanto, Y., Sustiyah, S. Zubaidah, B. Satata. 2016. Pemanfaatan kotoran sapi sebagai sumber biogas rumah tangga di Kabupaten Pulang Pisau Provinsi Kalimantan Tengah. J. Udayana Mengabdi 15:150158.

Sumanto, E., Juarini. 2006. Potensi Kesesuaian Lahan untuk Pengembangan Ternak Ruminansia di Provinsi Nusa Tenggara Timur. Prosiding Seminar Nasional Teknologi Peternakan dan Veteriner: Iptek sebagai Penggerak Pembangunan Sistem dan Usaha Agribisnis Peternakan. Bogor 4-5 Agustus 2004. Puslitbangnak, Balitbangtan. Bogor.

Tiwow, H.A.L., V.V.J. Panelewen,A.D. Mirah. 2016.Analisis potensi daya dukung lahan untuk pengembangan sapi potong di kawasan Pakakaan Kabupaten Minahasa. J. Zootek 36:476-486.

Weinzettel, J., E.G. Hertwich, G.P. Peters, K. Steen-Olsen, A. Galli. 2013. Affluence drives the global displacement of land use. Glob. Environ. Chang. 23:433-8.

Wiedmann, T., J. Barrett. 2010. A review of the ecological footprint indicator-Perceptions and methods. Sustainability 22: 1645-1693.

Wiesner, S., A.J. Duff, A.R. Desai, K. Panke-Buisse. 2000. Increasing dairy sustainability with integrated croplivestock farming. Sustainability 12:765-785.

Yuliani, D. 2014. Sistem integrasi padi ternak untuk mewujudkan kedaulatan pangan. J. Agroteknol. 4: $15-26$. 